DOI: $10.2478 / \mathrm{clb}-2019-0025$

\title{
TOPOS DIONISIAC ÎN ANTUMELE LUI LUCIAN BLAGA
}

\section{Lehel-Szabolcs Szakács \\ Universitatea de Medicină, Farmacie, Științe și Tehnologie, Târgu-Mureș}

\begin{abstract}
The purpose of this paper is to analyze the Dionysian topos in Lucian Blaga's poetry. The zero point of our work is the concept of geocriticism. This study tries to outline the fact that the space in Blaga's poetry features both Dionysian and Apollonian characteristics. In the center of this dichotomic space stands the symbol of the mountain - a sacred area where a whole cosmogony comes to life, based on the dialectic relationship between ascent and descent.
\end{abstract}

Key-words: Geocriticism, Dionysian, Apollonian, mountain, narcissism

Lucian Blaga a debutat simultan cu Poemele luminii şi volumul de aforisme Pietre pentru templul meu, în anul 1919. Cele două opere ale tânărului Blaga au beneficiat de o primire favorabilă din partea criticilor din acea perioadă. Încă înainte de apariție, Sextil Pușcariu a scris despre Poeme în Glasul Bucovinei, nr. 49, 3/ 16 ian. 1919, iar, după apariție, volumul a fost întâmpinat de Nicolae Iorga într-un articol intitulat „Rânduri pentru un tânăr” (în revista Neamul românesc, nr. 88, 30 apr. 1919). Nici ceilalți critici ai vremii nu s-au distanțat de optimismul primilor doi: cronicari literari, precum I. Agîrbiceanu, N. Davidescu, Ovid Densusianu, D. Botez, Ion Vinea, Ion Breazu sau Octav Şuluţiu, au văzut în Blaga un poet de mare perspectivă. Entuziasmul criticilor se va aplana odată cu apariția piesei Zamolxe, mister păgân și a volumului Paşii profetului. Expresionismul lui Blaga intră în conflict cu spiritul conservator care, încă domina perioada respectivă. Odată cu apariția articolului lui Ion Breazu („,Opera poetică a lui Lucian Blaga”, în rev. Cosânzeana, nr. 2 şi 3, ian. 1926), opera lui Blaga reintră în centrul atenţiei criticii literare și rămâne acolo până în anul 1946, când operele poetului vor intra sub cenzură. Poeziile și volumele de filosofie rămân aproape „neatinse” de critică literară timp de două decenii. O schimbare semnificativă vor aduce anii 70-80 ai secolului trecut. Această perioadă se caracterizează printr-o intensă activitate de recuperare a operei poetului. În acești ani, apar cele mai importante studii despre opera lui Lucian Blaga, studii semnate de Eugen Todoran, George Gană, Ion Pop sau Dan C. Mihăilescu. ${ }^{1}$

Procesul de (re)interpretare este în curs de desfășurare și în zilele noastre, opera lui Blaga oferind mereu noi posibilități de interpretare. În lucrarea de față, dorim să prezentăm modul în care spațiul se reflectă în poezia antumă a lui Lucian Blaga, punând accent pe dihotomia apolinic-dionisiac. Ca punct de plecare, vom folosi teoriile geocriticii, precum și studiile celor mai importanți critici literari de ieri și de azi. Scopul lucrării noastre este acela de a

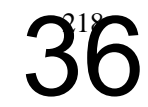


demonstra că în poeziile antume ale lui Lucian Blaga se reflectă un spațiu care oscilează între contemplația apolinică şi frenezia dionisiacă.

Anii 1960-1970 au propus o nouă paradigmă a spațiului. Călătoria lui Iuri Gagarin în spațiu, respectiv călătoria lui Neil Armstrong pe Lună au condus la necesitatea de a reinterpreta noțiunile de spațiu și loc atât în cadrul științelor exacte, cât și în domeniul literaturii. Teoreticianul american Tim Cresswell, definește relația dintre cele două noțiuni astfel: „Conceptul de spațiu este mult mai abstract decât cel de loc [...]. Spațiile au suprafețe și volume. Locurile au spații între ei."

Opțiunea noastră pentru noțiunea de topos ${ }^{1}$ se justifică prin faptul că, la Blaga, noțiunea de spațiu este strâns legată de cele de dionisiac și apolinic, astfel ea nu mai denumește o entitate fizică sau metafizică, ci mai degrabă un model cultural.

Cercetătoarea britanică Nicola Thomas vorbește despre „limbă ca imaginar". ${ }^{1}$ Făcând o aplicaţie pe poezia lui J. H. Prynne și Paul Celan, autoarea scoate în evidență modul în care limbajul poetic se împletește cu peisajul ("landscape") și devine un ,imaginar textual". Prin această sintagmă se înțelege reprezentarea unui spațiu real sau imaginar cu ajutorul emoțiilor, metaforelor sau al simbolurilor. ${ }^{1}$ Acest imaginar înţeles drept,text ca peisaj și peisaj ca text" ${ }^{\prime 1}$ va avea în centru un „meridian”, adică un spațiu ambivalent, în care „se împletește aproapele cu îndepărtatul, legătura cu ruptura și abstractul cu concretul", iar modul în care poetul reflectă asupra acestui spaţiu, va conferi un caracter autoreflexiv poeziilor sale. În poezia lui Blaga, prezența "imaginarului textual" este cu atât mai evidentă cu cât în centrul filosofiei poetului se află metafora plasticizantă și cea revelatorie. Prin acestea se reflectă un peisaj care e în concordanță cu stările poetului dând astfel un caracter reflexiv operei.

Pe de altă parte, și la Blaga putem vorbi de un „meridian”. Criticul Cornel Moraru observă în acest sens că:,,Mai toate comentariile critice de până acum au evidențiat că în mitul poetic al lui Lucian Blaga simbolul central se constituie dintr-un topos al ascensiunii, manifestat în reprezentările hierocosmice arhaice, cum ar fi Muntele sau Arborele cosmic."1 În mitologie, muntele era un loc sacru, care de obicei era asociat cu ascensiunea și - implicit - cu cosmogonia: „Vârful Muntelui Cosmic este nu numai punctul cel mai înalt de pe Pământ, ci şi buricul Pământului, punctul din care s-a declanşat creația." "Poezia Munte vrăjit vine în sprijinul acestor afirmații. Aici, muntele este văzut ca o ,poartă” și ca o ,punte”, astfel el nu este doar un simbol al ascensiunii, ci și al deschiderii spre un alt tărâm: „Intru în munte. O poartă de piatră/ încet s-a-nchis. Gând, vis şi punte mă saltă./ Ce vinete lacuri! Ce vreme înaltă!".

Alături de munte, deseori apare și lacul, care reflectă cerul. Această oglindă uriașă are conotaţii apolinice, dacă avem în vedere natura

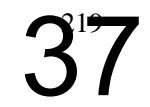


contemplativă a spiritului poetic blagian. Considerându-se pe sine ca o răsfrângere a lumii, el simte nevoia de a se privi într-o oglindă care are dimensiuni asemănătoare lumii, numai ,așa redescoperă el senzația sublimului și a privirii pline de încântare în faţa realului [...]." În Eneade al lui Plotin, Dionysos e înfățişat privindu-se într-o oglindă, iar această privire parcă se datorează dorinței de a crea o lume nouă, asemănătoare frumuseții sale. Aceste aspecte legate de mitul lui Dionysos pot fi regăsite şi în volumul Paşii profetului. Aici, atmosfera selenară este dominată de un sentiment de imobilitate, de împietrire. Întreg spațiul reflectă starea de spirit a poetului. Dacă în alte volume, muntele este un simbol al ascensiunii şi al cosmogoniei, în acest volum muntele este asociat cu sensuri negative: „Din vârf de munți amurgul suflă" (Amurg de toamnă). În altă ordine de idei, muntele nu mai este văzut ca o poartă sau o punte, ci ca o sursă a răului. Întreg universul pare întors pe dos: lumina vine din apus („O rază/ ce vine goană din apus”), iar în poemul Vara este înfățișat un peisaj de-a dreptul apocaliptic, cu fulgere fără glas asemenea unor picioare de păianjen smulse din trupul lor. „Eul indeterminat” se identifică - în esenţă - cu acest peisaj, în sensul în care „lacul oglindește stelele, fiindcă vrea să fie cer." Datorită acestei aspirații nietzscheene, volumul Paşii profetului va fi pus sub semnul zeului Pan. 'Iată cum spaţiul poetic blagian devine o oglindă narcisică a stărilor poetului.

Imaginea muntelui apare adesea însoțit de imaginea lacului care reflectă cerul, deschizând astfel în planul teluricului o zonă de interferență dintre înalt şi adânc. Poezia Iezerul este un exemplu elocvent: „În pâlnia muntelui iezerul netulburat/ ca un ochi al lumii, ascuns, s-a deschis./ Oglindește un zbor prea înalt și ceasul/ curat, ce i-a fost odată promis.// Cată lung Ochiul spre Nord și spre vârste,/ și mulcom apoi spre vânătul cer./ Visează-n amiază spre rodii de aur,/ care se coc, senine, în ger." Putem vorbi aici de un narcisism cosmic. Spre deosebire de narcisismul activ (care se bazează pe principiul ,sunt frumos pentru că natura este frumoasă, iar natura este frumoasă pentru că eu sunt frumos"1 și se realizează printr-o reflectare clară, netulburată), narcisismul cosmic - așa cum îl înțelege Bachelard presupune un cadru selenar, neclar. „E ca şi cum obiectele ar fi lipsite de voinţa de a se reflecta." "Pe de altă parte,Gaston Bachelard vorbește despre măsura în care condițiile aerului și ale luminii ne permit să cunoaștem esența peisajului. ${ }^{1}$ Toate acestea, aplicate la poezia lui Blaga, ar rezulta relația dialectică dintre metafora revelatorie și cea plasticizantă, respectiv cunoaşterea luciferică și cea paradisiacă. În contextul de față, narcisismul cosmic este echivalentul geografiei mitice în măsura în care rezultatul oglindirii este o lume care este capabilă să potențeze misterul.

La o primă vedere, am putea considera că narcisismul face trimitere mai degrabă la starea apolinică, decât la cea dionisiacă. Observația e justă, totuşi noi am vorbit despre apolinic şi dionisiac bazându-ne pe ideea că, în

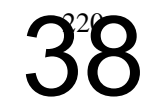


opera lui Lucian Blaga, nu putem vorbi de o reprezentare dionisiacă pură, deoarece ascensiunea este mereu contrabalansată de coborâre, iar exaltarea de contemplare. Astfel, în poezia antumă a lui Blaga, dionisiacul și apolinicul nu sunt elemente antitetice, ci complementare care împreună formează imaginarul blagian, prin intermediul mecanismelor limbajului și al mecanismelor poetice.

În concluzie, putem considera că toposul blagian este bazat pe dihotomia dionisiac-apolinică. În centrul acestui spaţiu se află muntele, un loc sacru al cosmogoniilor. Lacul, aflat de obicei pe munte, este principalul simbol al apolinicului, în care se reflectă cerul și universul. Acesta fiind asemănător cu o oglindă, putem vorbi de un narcisism cosmogonic al cărui cadru obscur oferă posibilitatea de a crea o lume a cărei esență este un mister.

Prin urmare, putem afirma că geografia blagiană este oglinda unei conștiințe poetice frământate, neîmpăcate cu lumea transcendentală (fapt care este vizibil, mai ales, în volumul Paşii profetului).

\section{BIBLIOGRAFIE}

I. Bibliografia operei

Blaga, Lucian, Opera poetică , Cuvânt înainte de Eugen Simion, Prefaţă de George Gană, Ediție îngrijită de George Gană și Dorli Blaga, Editura Humanitas, București, 1995.

Blaga, Lucian, Elanul insulei. Aforisme și însemnări, Prefaţă, text stabilit și note de George Gană, ed. îngr. de Dorli Blaga și George Gană, Editura Dacia, Cluj-Napoca, 1977.

II. Volume de teorie şi critică literară

Bachelard, Gaston, Apa și visele. Eseu despre imaginația materiei, Traducere și tabel bibliografic de Irina Mavrodin, Editura Univers, București, 1995.

Cresswell, Tim, Place: A Short Introduction, Oxford: Blackwell, 2004.

Eliade, Mircea, Imagini și simboluri, Editura Humanitas, București, 1994.

Moraru, Cornel, Lucian Blaga. Monografie, antologie comentată, receptare critică, Editura Aula, Brașov, 2004.

Moraru, Cornel, Lucian Blaga. Convergențe între poet și filosof, Editura Ardealul, Tg. Mureș, 2005.

Thomas, Nicola, Space, place and poetry in English and German, 1960-1975, Palgrave Macmillan, Londra, 2018. 